(C) 2016, Elsevier. Licensed under the Creative Commons Attribution-NonCommercialNoDerivatives 4.0 International http://creativecommons.org/licenses/by-nc-nd/4.0/

\title{
Small lakes in big landscape: Multi-scale drivers of littoral ecosystem in alpine lakes
}

\author{
Dragos G. Zaharescu ${ }^{1,2,3^{*}}$, Carmen I. Burghelea ${ }^{1,3}$, Peter S. Hooda ${ }^{2}$ Richard N. Lester ${ }^{4}$ and Antonio \\ Palanca-Soler ${ }^{3}$ \\ ${ }^{1}$ Biosphere 2, University of Arizona, Tucson, Arizona, USA \\ ${ }^{2}$ School of Built and Natural Environments, Kingston University London, UK \\ ${ }^{3}$ Faculty of Biological Sciences, University of Vigo, Vigo, Spain \\ ${ }^{4}$ Formerly at Birmingham University Botanic Gardens, Birmingham, UK, who \\ passed away in 2006
}

*Corresponding author: D.G.Zaharescu, zaharescu@email.arizona.edu, zaha_dragos@yahoo.com

C.I. Burghelea: bcarmen@email.arizona.edu

P.S. Hooda: p.hooda@kingston.ac.uk

A. Palanca-Soler: apalanca@uvigo.es

Running title: Multi-scale drivers of alpine littoral ecosystem 
(C) 2016, Elsevier. Licensed under the Creative Commons Attribution-NonCommercialNoDerivatives 4.0 International http://creativecommons.org/licenses/by-nc-nd/4.0/

\section{Abstract}

In low nutrient alpine lakes, the littoral zone is the most productive part of the ecosystem, and it is a biodiversity hotspot. It is not entirely clear how the scale and physical heterogeneity of surrounding catchment, its ecological composition, and larger landscape gradients work together to sustain littoral communities.

A total of 113 alpine lakes from the central Pyrenees were surveyed to evaluate the functional connectivity between littoral zoobenthos and landscape physical and ecological elements at geographical, catchment and local scales, and to ascertain how they affect the formation of littoral communities. At each lake, the zoobenthic composition was assessed together with geolocation, catchment hydrodynamics, geomorphology and topography, riparian vegetation composition, the presence of trout and frogs, water $\mathrm{pH}$ and conductivity.

Multidimensional fuzzy set models integrating benthic biota and environmental variables revealed that at geographical scale, longitude unexpectedly surpassed altitude and latitude in its effect on littoral ecosystem. This reflects a sharp transition between Atlantic and Mediterranean climates and suggests a potentially high horizontal vulnerability to climate change. Topography (controlling catchment type, snow coverage and lakes connectivity) was the most influential catchment-scale driver, followed by hydrodynamics (waterbody size, type and volume of inflow/outflow). Locally, riparian plant composition significantly related to littoral community structure, richness and diversity. These variables, directly and indirectly, create habitats for aquatic and terrestrial stages of invertebrates, and control nutrient and water cycles. Three benthic associations characterised distinct lakes. Vertebrate predation, water conductivity and $\mathrm{pH}$ had no major influence on littoral taxa.

This work provides exhaustive information from relatively pristine sites, and unveils a strong connection between littoral ecosystem and catchment heterogeneity at scales beyond the local environment. This underpins the role of alpine lakes as sensors of local and large-scale environmental changes, which can be used in monitoring networks to evaluate further impacts.

Keywords: Alpine lakes; Littoral zone; Benthic invertebrates; Scale dependency; Catchment heterogeneity; Riparian vegetation; Vertebrate predation; Environmental change. 
(C) 2016, Elsevier. Licensed under the Creative Commons Attribution-NonCommercial-

NoDerivatives 4.0 International http://creativecommons.org/licenses/by-nc-nd/4.0/

\section{Introduction}

Integrative efforts linking landscape-scale biogeochemical, hydrological and ecological processes have been intensified in the last decade, and true whole-catchment perspectives are starting to crystalize (Richter and Billings 2015). Alpine catchments are of increased relevance, partly because they are younger than the average landscape, and they are major drivers of hydrological and biogeochemical cycles affecting the wider biosphere. Their high topography, remoteness and climate allow for the formation of waterbodies of unmatched water quality, which are ecological, biogeochemical and aesthetic hotspots.

Only across Europe, there are over 50,000 remote mountain lakes (Kernan et al., 2009), of which the Pyrenees, a relatively low-density lacustric region, accounts for an estimated 4,000 (Castillo-Jurado, 1992). The littoral and riparian zones of these lakes are critical mediators between sediment and nutrient fluxes from the surrounding terrestrial area and lake internal processes. Littoral surfaces also experience cross-ecosystem water and nutrient exchanges (both, autochthonous and allochthonous) with riparian zones, and provide habitat and resources for both aquatic and emerging stages of many aquatic taxa, such as most benthic insects (Gregory et al., 1991; Jonsson and Wardle; 2009; Kopacek et al., 2000). The Pyrenees are estimated to have $>797 \mathrm{~km}$ of littoral zone in lakes above $1000 \mathrm{~m}$, which are of at least 0.5ha (Castillo-Jurado, 1992), meaning that littoral processes represent a great portion of the nutrient fluxes in the catchment.

The topography, the hydrology, the bedrock geology and the climate control the intensity of bedrock weathering and nutrient transport into alpine lakes; this influences water and sediment chemistry, and ultimately their ecosystems (Vollenweider, 1968). Even though the littoral zone is just a fraction of the total lake area, it harbours the vast majority of species in a lake, and the littoral nutrient productivity is vital for aquatic food webs, contributing substantially to the whole lake ecosystem energy budget (Vander-Zanden et al., 2006, Vadeboncoeur et al., 2011).

The challenges from inhabiting shallow lake areas at high elevation, range from high solar radiation and water level fluctuations, to low food availability, a short growing season, irregular freezing periods and strong seasonal temperature variation (Bretschko, 1995). Most of the aquatic invertebrates are at their distributional boundaries, and they are highly sensitive to environmental change (Bandyopadhyay et al., 1997). For example, winter mortality is a major factor regulating alpine lake macroinvertebrate populations (Oswood et al., 1991). Food availability and duration of ice/snow cover during winter are other factors affecting littoral macroinvertebrate communities (Bretschko, 1995), as 
(C) 2016, Elsevier. Licensed under the Creative Commons Attribution-NonCommercial-

NoDerivatives 4.0 International http://creativecommons.org/licenses/by-nc-nd/4.0/

there are also nitrate concentrations (from acid deposition), fish presence, lake morphology (Kernan et al., 2009) and type of shore coverage (Füreder et al., 2006).

Elevated topography and low available nutrients generally support simple littoral ecosystems, which are characterized by a limited number of species and trophic levels (as compared with lowland lakes; Magnea et al., 2013), and are highly adapted to local environment. Research has shown that in mountain lakes, variability in terrestrial conditions can affect littoral macroinvertebrate abundances, through relative control on the proximal environment (Kernan et al., 2009). Moreover, geographical location can have a greater influence on macroinvertebrate communities than local environment (Kernan et al., 2009). It is expected that these topographical and climate restrictions introduce strong biogeographical variability and segregation of littoral macroinvertebrates into distinct communities. Climate/environmental change would further disrupt this natural heterogeneity, through mechanisms that alter the temperature, water and nutrient fluxes, significantly changing lake ecosystem balances. For example the functional diversity of alpine stream benthic invertebrate communities can be particularly affected by climate change-driven glacier retreat (Khamis et al., 2014).

Despite a great ecological and geochemical importance of the alpine lakes' littoral zone, the scale and complexity of its connectivity to surrounding landscape remains an open question. To better anticipate its response to environmental change it is, therefore, imperative to integrate the littoral surfaces into the mechanistic understanding of how physical and ecological heterogeneity of the catchment and littoral ecosystem interact across spatial scales before major alterations occur. This study attempts to evaluate the magnitude of the influence catchment attributes have on littoral macrozoobenthos community composition at scales from a lake to large geographical gradients. A second aim was to assess how these interactions determine the formation of littoral associations, which can potentially serve as sensors of environmental change. We hypothesize that while local littoral environment directly mediates the macroinvertebrate community, its composition is also sensitive to landscape processes at scales beyond that of the lake, through mechanisms that can affect both aquatic and terrestrial phases of its taxa. The study area has the advantages of being at the confluence of four major biogeographical regions: Atlantic, Continental, Mediterranean, and Alpine, which should facilitate capturing the large-scale heterogeneity in a relatively narrow region. 
(C) 2016, Elsevier. Licensed under the Creative Commons Attribution-NonCommercial-

NoDerivatives 4.0 International http://creativecommons.org/licenses/by-nc-nd/4.0/

\section{Methodology}

\subsection{The lakes under study}

A total of 113 lakes were surveyed in July 2001 in the axial Pyrenees, between degrees: $42^{\circ} 51^{\prime} 34.76^{\prime \prime}-42^{\circ} 43^{\prime} 8.19^{\prime \prime} \mathrm{N}$ and $0^{\circ} 29^{\prime} 44.39 " \mathrm{~W}$ - $0^{\circ} 8^{\prime} 40.29 " \mathrm{E}$ (Fig. 1, Supplementary List 1). Their selection was largely dictated by their accessibility, and comprised a range of typical alpine ponds and lakes, with surface area varying between $9.4-107,068 \mathrm{~m}^{2}$. The area is within the boundaries of the Central Pyrenees National Park, France, and comprises a series of postglacial catchments on cirque and valley floors. Catchment geology varied between the various valleys and it was dominated by two large geologic units: in the central area and at the extreme east, lake catchments lie on acidic bedrock (granite batholith) while in between, granitic batholiths are surrounded by metasedimentary and sedimentary materials such as slate, limestone and sandstone (Zaharescu, 2011).

Most of the study lakes are above the tree line (altitudes ranged from 1580-2501 m a.s.l.; mean $=2212 \mathrm{~m}$ a.s.I.), and they are largely undisturbed by human activity. Low-level agro-pastoral activities, leisure fishing and trekking are among the very few activities allowed in the park. Two of the sampled lakes were transformed into reservoirs (lakes Artouste and Ossoue), and they are being used as freshwater reserve. The great majority of study lakes are oligotrophic. Their proximal catchment area (roughly $10-20 \mathrm{~m}$ around the lake) has generally low vegetation coverage $(<20 \%)$, but this varies according to topography and location. Loose rocks dominate on most of the lake shores, though they were more abundant on the steeply slopes of granitic catchments (Zaharescu, 2016a).

The hydrological network, consisting of temporary and permanent lakes, ponds, pools and streams, is a natural legacy of the last glaciers retreat more than 5,000 years ago. Water input in most lakes is by direct precipitation and permanent streams; glaciers and springs were present only in a few cases. The water level in these lakes is a balance between precipitation input, seasonal water loss and lake basin capacity. Their geographical location on the north range of the Pyrenees, means they are at their full capacity most of the year. Surface connectivity between lakes varied for the lakes investigated. Slope and bank snow coverage at the time of sampling was generally low, but had higher coverage at the head of catchments. Water $\mathrm{pH}$ was mainly neutral (mean $=7.6$ ), but varied between 5.2 (in granitic and Sphagnum moss vegetated waterbodies) and 8.8 (in lakes on schist and limestone) (Supplementary List 1). Conductivity was low, averaging $38 \mu \mathrm{sm}^{-1}$ and positively related to $\mathrm{pH}$ (Pearson correlation, $\left.r^{2}=0.18, p<0.01\right)$. Neither parameter varied greatly between surface and bottom measurements.

\subsection{Sampling strategy and data collection}


(C) 2016, Elsevier. Licensed under the Creative Commons Attribution-NonCommercialNoDerivatives 4.0 International http://creativecommons.org/licenses/by-nc-nd/4.0/

An exhaustive assessment was conducted for each visited lake (Fig. 1). Because the response of benthic ecosystem to physical, chemical and ecological factors in the surrounding environment is expected to change with increasing landscape heterogeneity, composition and scale, we sampled major environmental parameters likely to influence biotic composition along a gradient of local, catchment and geographical scale influences. Local variables included littoral macroinvertebrates, water $\mathrm{pH}$ and conductivity, and the presence of vertebrate predators, i.e. frogs and trout. Catchment-scale parameters comprised ecotope properties of proximal part of lake catchment and riparian vegetation assemblages. We use the term "ecotope" to denote the integrated physical elements of a landscape that underlie an ecosystem, and that exchanges matter and energy with the surrounding environment (Zaharescu et al., 2016a). Geographical-scale influences were represented by horizontal and vertical gradients in, longitude, latitude and altitude.

Macroinvertebrate sampling deliberately targeted the littoral zone. This area generally supports far larger and more diverse populations of benthic invertebrates than the deeper zone (Vadeboncoeur et al., 2011). The littoral is also likely to relate more directly to the nearby riparian and catchment factors. Semi-quantitative 3 min kick-samples were collected in each lake using a standard pond net (Frost et al., 1971). Samples were collected at short distances while moving around the lake perimeter to cover different micro-habitats in proportion to their occurrence. Littoral substrate was highly variable and ranged from boulders to fine sands, vascular plants, mosses and algae. A composite sample (3-10 subsamples) was collected at each lake. In each visited lake about half of the perimeter was sampled. All substrates (rocks, cobbles, coarse and fine sand, epilithic moss, etc.) were sampled down to $60 \mathrm{~cm}$ water depth. Subsequently all samples were preserved in $96 \%$ alcohol for a comprehensive laboratory sorting and analysis. Benthic organisms were identified down to the lowest possible taxonomic level using Tachet et al. (2002) key, and counted under a stereomicroscope. The lowest taxonomic level identified (down to genus and species in some cases) of living and subfossil taxa will be regarded as morphotypes henceforth. For most statistical tests a family/subfamily level resolution was used. A list of identified taxons and their incidence is provided in Supplementary List 2.

Additionally, water $\mathrm{pH}$ and conductivity were recorded at the surface and the bottom $\pm 5 \mathrm{~m}$ off the shore) at each site with portable $\mathrm{pH}$ and conductivity probes. The water was collected with a standard bottom water sampler, following a clean protocol (Zaharescu et al., 2009). Presence of frogs (Rana temporaria) was visually inspected at each site. Trout presence data at each location was obtained from the stocking records maintained by the Pyrenees National Park. 
(C) 2016, Elsevier. Licensed under the Creative Commons Attribution-NonCommercialNoDerivatives 4.0 International http://creativecommons.org/licenses/by-nc-nd/4.0/

Riparian vegetation composition (presence/absence data) was recorded down to species level in the field at each site (for 50-100\% of lake perimeter), or on plants collected in a vasculum and identified off site, using multiple identification keys (Grey-Wilson and Blamey, 1979; Fitter et al., 1984; and GarcíaRollán, 1985). A detail description of the procedure is described in Zaharescu (2011) and Zaharescu et al. (2016b).

Furthermore, at each location, a number of catchment-scale factors were visually approximated according to dominant units. They were: nature of water input (whether meteoric, spring or stream) and output (whether absent, temporary, surface small, medium and large, subterranean or dam), tributary discharge (from absent to high discharge), water-body surface area, \% vegetation covering slopes and shore, slope (from flat to steep), main bedrock geology, presence of aquatic vegetation (from absent to abundant), shore development (1-4 fractal level), presence of snow deposits on the shore and in the catchment (\%), catchment type (postglacial geomorphology: plain, U- and V-shape valleys, valley head slope and mountain pass) and surface connectivity with other waterbodies (whether absent, surrounded by a larger lake, connected with a second one, or in chain). They are detailed in Zaharescu (2011) and Zaharescu et al. (2016a).

Lake geolocation was recorded with a portable GPS and provided in Supplementary List 1.

\subsection{Data analyses}

Statistical data analyses included principal component analysis (PCA), fuzzy set ordination (FSO), multidimensional FSO (MFSO), cluster and indicator species analyses. For this, environmental factors were split into groups, i.e. geolocation, landscape/ecotope, invertebrate-vertebrate interaction, water chemistry and riparian vegetation.

\subsubsection{Principal Component Analysis}

First, the landscape variables were reduced to a limited number of meaningful composite factors (Principal Components) by using the PC regression scores from PCA, after maximizing their fit to variable groups (Varimax rotation). These composite factors were used as predictors of littoral zoobenthos in further fuzzy set analysis (Table 1). By default, the Varimax rotated principal components are uncorrelated.

\subsection{2 (Multidimensional) Fuzzy Set Ordination}

To analyse the relationship between littoral zoobenthos composition (presence-absence data) and environmental gradients we used fuzzy set ordination (FSO) followed by stepwise multidimensional 
(C) 2016, Elsevier. Licensed under the Creative Commons Attribution-NonCommercial-

NoDerivatives 4.0 International http://creativecommons.org/licenses/by-nc-nd/4.0/

FSO (MFSO; Roberts, 2008). For this, a distance (dissimilarity) matrix computed with Sørensen similarity index of invertebrate presence-absence data was first calculated. This gave a measure of similarity between sites based solely on biotic composition (Boyce, 2008). Additionally, two more variables assumed to describe zoobenthos community structure were used in a (M)FSO with vegetation presenceabsence data matrix (Sørensen similarity index). They were taxon (family) richness and sequential diversity comparison index, which is a simplified method for estimating relative differences in biological diversity (SCl; Barbour et al., 1999), and allowed considering morphotypes in the analysis (Equation 1), where run describes the morphotype and taxon refers to family classification:

$$
S C I=\frac{\text { no.of runs } x \text { no.of taxa }}{\text { total no. of individuals }}
$$

(Equation 1)

Fuzzy set ordination (FSO) concept (Roberts, 1986) is a generalised alternative to traditional ordination approaches, such as canonical correspondence analysis, in which cases are assigned gradual membership (fuzzy) values ranging from 0 to 1 (Roberts, 2008), instead of 0 or 1 (i.e. in-or-out of a given set) like in classical statistics. FSO is expected to perform better than other models on more complex data sets, and it is insensitive to noise in environmental factors and rare species (Roberts, 2009).

Variables were first screened in turn in FSO, and those with highest correlation with the zoobenthos distance matrix (at >95\% efficiency) were retained for further MFSO. Technically, in MFSO, a FSO is performed on the variable that accounts for most of the variation first. Then, the residuals of the analysis are used with the next most important variable. The process is repeated until no more variables are left. Because only the fractions of variable membership that are uncorrelated are used by MFSO, each variable selected by the model is regarded as an independent process. This gives a high interpretability to the model (Roberts, 2008). Visually, the effect extent of each variable can be assessed by the increment in the correlation value attributable to that variable.

A total of 1000 random permutations were subsequently performed to test the significance of each variable in FSO/MFSO. Where the distance matrix was disconnected (sites and groups of sites with no shared species) or the dissimilarity was too high, a step-across function was applied to improve the MFSO. This finds the shortest paths to connect groups and removes rare observations/groups of observations (Oksanen, 2008).

Because trout and frog variables were binary, and to achieve more accurate $R^{2}$ in the model, these variables were standardized by Hellinger transformation (Legendre and Gallagher, 2001) before using them in FSO. 
(C) 2016, Elsevier. Licensed under the Creative Commons Attribution-NonCommercial-

NoDerivatives 4.0 International http://creativecommons.org/licenses/by-nc-nd/4.0/

\subsubsection{Mantel test}

To further assess the potential effect of riparian vegetation composition on major littoral invertebrate composition a Mantel test was performed on their distance matrixes. These matrixes were calculated with Baroni-Urbani \& Buser similarity index. This index was preferred as it maximises the Pearson product-moment correlation coefficient between the two matrixes. A high significance of the correlation procedure was drawn after 9999 random permutations of Monte Carlo test. Mantel test was further used to test for the relationship between vegetation structure (computed using Sorensen similarity index) and zoobenthos family richness and morphotype diversity.

\subsubsection{Community analysis}

Finally, the littoral zoobenthos data (family presence-absence) was analysed for co-occurring taxa and their ecotope preferences. This was achieved by clustering the sites on the basis of shared species, and applying indicator species analysis for each resulting cluster. First, a flexible linkage PairGroup Method using the Arithmetic Averages (PGMA; method parameter $=0.85$ ) cluster analysis was run on a distance matrix computed from Sørensen similarity matrix of families presence-absence data. Plotting cluster solutions in discriminating space (by discriminant analysis) helped evaluate the reliability of cluster solution. Secondly, indicator species analysis was run at the nodes of the major clusters to identify invertebrate families that represent the resulting lake groups.

FSO and LabDSV packages were used to compute FSO and MFSO (Roberts, 2007a; Roberts, 2007b); ADE4, CLUSTER and FPC packages for Mantel test, clustering (Thioulouse et al., 1997; Kaufman and Rousseeuw, 1990; Hennig, 2005), and LabDSV for indicator species analysis (Dufrene and Legendre, 1997), all for the R statistical language and environment (R Development Core Team, 2005).

\section{Results and discussion}

\subsection{Littoral diversity, landscape structure and scale}

\subsubsection{Large geographical gradients}

Biome variability across geographic areas generally follows large-scale gradients in climate and topography. Results of FSO and MFSO of family composition against altitude, latitude and longitude showed that individually, these three factors could reliably predict littoral taxa composition (Fig. 2). The relative contribution of these variables to MFSO and their cumulative value are illustrated in Fig. 3. Longitude exerted by far the largest independent contribution, while altitude and latitude appeared to 
(C) 2016, Elsevier. Licensed under the Creative Commons Attribution-NonCommercial-

NoDerivatives 4.0 International http://creativecommons.org/licenses/by-nc-nd/4.0/

incorporate a large covariant component with the former, as shown by their low significance ( $P$ value) as independent factors.

Compositional and functional changes in zoobenthos across large horizontal and vertical gradients have been reported before, and whole biome models have been used to evaluate changes in taxon distribution likely to occur with a changing climate (Colwell et al., 2008, IPCC, 2014). At an estimated $60 \mathrm{~km}$ longitudinal span, the study area is relatively narrow. Nevertheless, longitude dominance in the model appears to be given by the area's unique position at the confluence of Atlantic and Mediterranean biogeographic regions (Fig. 1), which imprinted a sharp horizontal change in ecosystem composition. The two macro-regions are characterised by major climatic differences in water availability and temperature (López-Moreno et al, 2008), with Mediterranean climate being generally warmer, drier and comparatively of larger inter-seasonal variability than the Atlantic climate. This means potential tipping points in alpine lake ecosystems due to climate change effects (particularly through sharp changes in water temperature and dynamics; Khamis et al., 2014) is likely to happen faster across horizontal than vertical gradients in biogeographical boundary regions such as this one, with potentially unexpected effects. The changes could affect ecological processes such as niche retention in benthic biota, but they could also potentially affect longer-term biotic speciation in these regions (Doebeli and Dieckmann, 2003). This could be accentuated by the generally simpler composition of alpine benthic ecosystems as compared to lowlands (Magnea et al., 2013).

\subsubsection{Catchment scale drivers}

Principal component analysis (PCA) revealed three composite factors (Table 1). These factors were interpreted as: PC1, hydrodynamics (summarising input size, input and output nature, and lake size); PC2, geo-morphology (i.e. \% vegetated shores and slopes, shore slope, geology, aquatic vegetation and shore development); and PC3, topography formation (catchment type, \% shore and catchment snow coverage, connectivity with other lakes). They are exhaustively reported in Zaharescu et al. (2016a). The response of littoral invertebrates to these catchment factors is illustrated in Figures 2 (FSO) and 3 (MFSO). Both, univariate and multivariate solutions of the models show that topography was the most important predictor of littoral biota composition at a high degree of confidence $(p<0.06)$, followed by hydrodynamics (Figs. 2 and 3). Topography exerts its influence mainly through its structural variables: catchment type, shore and catchment snow coverage and connectivity with other lakes. These variables would sustain habitats at larger scale (e.g. lake's proximal catchment), and allow connectivity among populations of benthic communities, which need adequate habitats in both, aquatic and riparian areas 
(C) 2016, Elsevier. Licensed under the Creative Commons Attribution-NonCommercial-

NoDerivatives 4.0 International http://creativecommons.org/licenses/by-nc-nd/4.0/

for survival. For instance, lakes at the head of glacial valleys, with snow presence most of the year, would harbour functional taxa with adaptation for near-freezing environment, very low nutrient input, and short reproductive time. On the other hand, valley floor lakes would harbour organisms with longer emergence periods, requiring additional nutrient and material inputs from the catchment, and allowing more diverse periphyton communities that serve as food and microhabitats for the zoobenthos. This ecosystem would also likely be more vulnerable to larger periods of snow presence.

While hydrodynamics was significant in FSO (Fig. 2), its small influence in MFSO can be explained by a high co-variability with topography (Fig. 3). The secondary effect of lake hydrodynamics suggests contributions from water source and lake area. For instance, large stream-fed lakes that maintain a continuous surface flow throughout the summer, would also maintain a generally low temperature and a heterogeneous structure of littoral habitats. Conversely, in relatively small waterbodies, dominantly fed by catchment runoff and/or snowmelt (therefore not sourced by continuous streams), the littoral surface can vary seasonally and warm faster. These different ecotopes will allow for the persistence of functional groups adapted to distinct lake environments, and they will vary with topography. This is supported by the results of studies conducted in other high altitude environments, which found clear differences in biotic assemblages in spring-fed streams under different flow regimes (Danehy and Bilby, 2009).

\subsubsection{Local scale effect}

\section{(a) Riparian vegetation}

Many of the benthic invertebrates, particularly insects, also have terrestrial phases. The relationship between littoral and riparian ecosystems may therefore go beyond their simple proximity or nutrient provision. (M)FSO model found a significant effect of plant species composition on the invertebrate diversity and family richness (cumulative $r=0.48, p<0.05$; Fig. 4). A relatively low but significant relationship was also found between the compositions of vegetation and benthic invertebrates (Mantel test, Monte Carlo $r=0.16, p<0.01$ ), which means commonly associated invertebrate groups are supported by commonly associated plant species. Although spatial covariability of flora and fauna along environmental gradients is not excluded, this relationship is meaningful in the sense that in the restricting alpine environment plant consortiums could provide niche separation for various competing invertebrates, including the terrestrial phases of most aquatic insects. This could include supplying nutrient for functional feeding groups, casing materials, microhabitats during short summer periods, and protection against excessive solar radiation (Gregory et al., 1991; Dudgeon, 2009). 
(C) 2016, Elsevier. Licensed under the Creative Commons Attribution-NonCommercialNoDerivatives 4.0 International http://creativecommons.org/licenses/by-nc-nd/4.0/

Other studies have highlighted the importance of riparian plant coverage to macroinvertebrate communities along streams, especially in strong transitional gradients such as grassland-forest (Stone et al., 2005), but also the vegetation type (Cummins et al., 1989; Angradi et al., 2001). Our findings support the idea that sparsely vegetated alpine catchments provide important functional links between riparian vegetation composition and the diversity, richness and functional composition of benthic invertebrates.

\section{(b) Vertebrate predation and water chemistry}

Littoral productivity is vital for supporting higher trophic levels in lakes (Vadeboncoeur et al., 2011), and the presence of predators such as fish or amphibians, particularly in alpine lakes can result in a top-down driven ecosystem (Eriksson et al., 1980). Results of the relationship between the presence of fish and amphibians, and invertebrate groups surprisingly showed no effect (Fig. 2). This is evidence of the broad composition of littoral fauna being highly resilient to vertebrate predation. It is possible that predators were size selective, affecting the abundance of easily accessible groups, such as chironomids (Orthocladiinae and Chironominae) and planktonic crustaceans (Kernan et al., 2009; Syväranta and Jones, 2009; Schilling et al., 2009). Another explanation is that the generally coarse littoral substrate together with shielding mechanisms insects use in alpine lakes to protect against high solar radiation could also be effective against vertebrate predation. Niche segregation between aquatic and terrestrial environments could have also played a role. It is known that alpine lake frogs would largely prey on the more abundant terrestrial insect phases (Vieites et al., 1997), which helps them maximise nutrient intake during aestival season. Carlisle and Hawkins (1998) who observed that physical habitat might be more important than predation in structuring benthic communities in trout-stocked mountain lakes further supports our results.

Water $\mathrm{pH}$ and conductivity, measures of acidity, total ionic/nutrient content and their bioavailability, important lake parameters, could not explain diversity variation in major zoobenthic groups (Fig. 2). They are both indicators of bedrock geology and lake metabolism, and can change significantly during thaw periods in mountain lakes, influencing biotic composition (Olofsson et al., 1995). The very low relationship observed for either surface or lake bottom ( $\mathrm{pH}$ and conductivity), suggests that their natural/seasonal variability in each lake may be strong enough to offset a direct response from biotic communities at a broader scale. 
(C) 2016, Elsevier. Licensed under the Creative Commons Attribution-NonCommercial-

NoDerivatives 4.0 International http://creativecommons.org/licenses/by-nc-nd/4.0/

\subsection{Major littoral communities}

Low nutrient and strong environmental variability of alpine systems are expected to induce biogeographical fragmentation and formation of biotic communities that are strongly dependent to local conditions. Flexible hierarchical clustering and indicator taxa analyses identified three large lake groups hosting distinct biota (Fig. 5 and Table 2).

The first lake community (type A; Table 2 and Fig. 5) was the largest and the most widespread, consisting of a significant number of spring-dwellers, which were tolerant to wide ranges in temperature, altitude, water flow regime, $\mathrm{pH}$ and micro-habitats (e.g. epi- and endobenthic, epilithic and epiphytic). They were mostly sedentary invertebrates of gill and tegumentary respiration, feeding largely on detrititus and microphytes. A small proportion were predators (e.g. Tanypodinae larvae) and parasitic (nematodes). Their dispersion mode was mostly passive aquatic and aerial, which facilitates habitat connectivity (Tachet et al., 2002). The relatively wide ecological breadth (eurytopic distribution) of this group means they can colonise a variety of headwaters. Association of Sphaeridae bivalves, Oligochaeta and Lumbriculidae worms with various members in this community has also been reported in headwaters of other alpine regions, including the Oregon Coast Range and the Himalayas (Danehy and Bilby, 2009; Manca et al., 1998).

The second community (type B, Table 2 and Fig. 5) was represented by omnivorous beetles and predatory dragonflies. Both are active groups, strong flyers as adults and capable of active colonisation and maintaining connected populations not always at easy reach. They also have long life cycles (>1year) and tolerate a wide range of temperatures. They have affinity to low water flow regime and heterogeneous microhabitats (Tachet et al., 2002), which most likely characterize the lakes cluster sharing this littoral group (Fig. 5).

The third littoral community (type C), had a low indicator value (Table 2). It was represented by craneflies, mosquitoes, water scavenger beetles and their parasitic worms. They share an aerial respiration (except gordiacea which are endoparasites in their larval stage) and a passive-to-active aerial dispersion mode in their adult stage. They tolerate a wide range of temperature and epibenthic microhabitats, with easy access to water surface where they breathe. Their feeding strategy is also diverse, from shredders (Limoniidae), to microphytes (Helophoridae), microinvertebrates and fine suspended matter (Culicidae) (Tachet et al., 2002). Females of most adult mosquitoes are ectoparasites.Further boxplot comparisons revealed that these communities did not display distinct preferences along the assessed catchment-scale variables (Supplementary Fig. 1). This, together with the wide ecological tolerance revealed by their taxon composition suggests ubiquitous distributions, 
(C) 2016, Elsevier. Licensed under the Creative Commons Attribution-NonCommercial-

NoDerivatives 4.0 International http://creativecommons.org/licenses/by-nc-nd/4.0/

which may have resulted from natural evolution of lake ecosystems, or they were determined by lake or terrestrial factors beyond those analysed herein.

\section{Conclusions}

The findings simplify the complexity and highlight the level of connectivity between the littoral ecosystem of alpine lakes and the physical and ecological heterogeneity of their catchment at a wide range of spatial scales. Longitude dominance over other large-scale gradients in its influence on the littoral zoobenthic composition reflected the biogeographic boundary between Mediterranean and Atlantic climates. This suggests that climate change effects on alpine lake ecosystem are likely to be stronger across horizontal gradients than the expected altitudinal distribution in biogeographical boundary regions - an overlooked vulnerability of the alpine biome.

Catchment Topography and hydrodynamics (in this order of influence) were the leading catchment-scale drivers of littoral community composition. These factors control lake hydrological and biogeochemical processes including water balance, nutrient fluxes in the catchment, riparian vegetation colonization, lake temperature and metabolism, which ultimately influence littoral habitat and community formation and population connectivity.

Although generally poorly developed, riparian vegetation composition provided the main local scale effect on littoral invertebrate community structure, indicating that the proximal terrestrial habitat is critical to maintaining the structure and functioning of the littoral ecosystem. Different plant assemblages could provide distinct microhabitats for the terrestrial phases of aquatic insects, sheltering against harsh conditions of solar radiation and wind, and supplying weathered nutrients and casing materials for the aquatic phases of many invertebrates.

Community analysis revealed that the studied lakes were characterised by the presence of three simple functional zoobenthic associations, of which the sedentary group was the largest and the most widespread among the lakes. Overall the findings demonstrate that the littoral ecosystem is connected to a variety of topographical, hydrological and ecological attributes from the terrestrial environment at scales extending from lake proximity, to its catchment and beyond. Protecting the long-term natural status of these lakes as well as incorporating them into natural observatory networks should be a management priority, as they can serve as reference sites for the environmental stress affecting their ecosystems at a wide variety of scales. 
(C) 2016, Elsevier. Licensed under the Creative Commons Attribution-NonCommercial-

NoDerivatives 4.0 International http://creativecommons.org/licenses/by-nc-nd/4.0/

\section{Acknowledgements}

This work was financially supported by Pyrenees National Park, France and Animal Anatomy Laboratory Foundation at Vigo University, Spain. We gratefully acknowledge field support by Andreea Vasiloiu, Javier Fernandez-Fañanas, Catalin Tanase, Nicolas Palanca-Castán, Jesús Giraldez-Moreira, Bruce Dudley and Cristina Castan-Lanaspa. We further thank Dave Roberts (Montana State University, USA) and Lasse Ruokolainen (Helsinki University, Finland) for the constructive conversation behind the statistical analyses.

\section{Authors contribution}

Sampling campaign design, A Palanca-Soler; data collection, A Palanca-Soler, DG Zaharescu and RN Lester; study design, sample and data analyses, DG Zaharescu and $\mathrm{Cl}$ Burghelea; manuscript preparation, DG Zaharescu, PS Hooda and Cl Burghelea.

\section{References}

Angradi TR, Hagan SM, Able KW. 2001. Vegetation type and the intertidal macroinvertebrate fauna of a brackish marsh: Phragmites vs. Spartina. Wetlands 21(1): 75-92.

Bandyopadhyay J, Rodda JC, Kattelman R, Kundzewicz ZW, Kraemer D. 1997. Highland waters- a resource of global significance. In: Messerli and Ives (Eds), Mountains of the world. A global perspective. The Parthenon Publishing Group Ltd.

Barbour MT, Gerritsen J, Snyder BD, Stribling JB. 1999. Rapid bioassessment protocols for use in streams and wadeable rivers: periphyton, benthic macroinvertebrates and fish. Second Edition. EPA 841-B-99002. U.S. Environmental Protection Agency: Office of Water. Washington, D.C.

Boyce R. 2008. Fuzzy set ordination web page. Northern Kentucky University. Accessed August 2009 from: http://www .nku.edu/ boycer/fso/.

Bretschko G. 1995. Opportunities for high alpine research, the lake "Vorderer Finstertaler See" as an example (Kühtai, Tirol, 2237 m a.s.l.). Limnologica 25: 105-108.

Carlisle DM, Hawkins CP. 1998. Relationships between invertebrate assemblage structure, 2 trout species, and habitat structure in Utah mountain lakes. J N Am Benthol Soc 17(3): 286-300.

Castillo-Jurado M. 1992. Morfometria de los lagos. Una aplicacion a los lagos del Pirineo. PhD thesis, University of Barcelona (in Spanish).

Colwell RK, Brehm G, Cardelús CL, Gilman AC, Longino JT. 2008. Global warming, elevational range shifts, and lowland biotic attrition in the wet tropics. Science 322: 258-261. 
(C) 2016, Elsevier. Licensed under the Creative Commons Attribution-NonCommercial-

NoDerivatives 4.0 International http://creativecommons.org/licenses/by-nc-nd/4.0/

Cummins KW, Wilzbach MA, Gates DM, Perry JB Taliaferro WB. 1989. Shredders and riparian vegetation. BioScience 39(1): 24-30.

Danehy RJ, Bilby RE. 2009. Periphyton and macroinvertebrate assemblage responses to flow regime in spring-fed headwaters. Verh Internat Verein Limnol 30(8): 1210-1214.

Doebeli M, Dieckmann U. 2013. Speciation along environmental gradients. Nature 421, 259-264.

Dudgeon D. 2009. The influence of riparian vegetation on macroinvertebrate community structure in four Hong Kong streams. J Zool 216(4): 609-627.

Dufrene M, Legendre P. 1997. Species assemblages and indicator species: the need for a flexible asymmetrical approach. Ecol Monogr 67(3): 345-366.

EEA (European Environment Agency). 2001. Biogeographical regions, Europe 2001. Accessed February 22, 2010 at: http://www.eea.europa.eu/data-and-maps/ figures/biogeographical-regions-europe2001.

Eriksson MOG, Henrikson L, Larsson P, Nilsson BI, Oscarson HG, Stenson JAE. 1980. Predator-prey relations, important for the biotic changes in acidified lakes. Ambio 9: 248-249.

Fitter RSR, Fitter A, Farrer A. 1984. Grasses, sedges, rushes and ferns of Britain and Northern Europe. Collins, London, UK.

Frost S, Huni A, Kershaw WE. 1971. Evaluation of a kicking technique for sampling stream bottom fauna. Can J Zool 49: 167-173.

Füreder L, Ettinger R, Boggero A, Thaler B, Thies H. 2006. Macroinvertebrate diversity in Alpine lakes: effects of altitude and catchment properties. Hydrobiologia 562: 123-144.

García-Rollán M. 1985. Claves de la flora de España (peninsula y baleares). Vol.II: dicotiledoneas (I-z) / monocotiledoneas. Mundi-Prensa [in Spanish].

Gregory SV, Swanson FJ, McKee WA, Cummins KW. 1991. An ecosystem perspective of riparian zones. BioScience 41(8): 540-551.

Grey-Wilson C, Blamey M. 1979. The alpine flowers of Britain and Europe. Collins, London, UK.

Hennig C. 2005. A method for visual cluster validation. In: Weihs, C. and Gaul, W. (eds), Classification the ubiquitous challenge. Springer, Heidelberg 2005: 153-60.

Intergovernmental Panel on Climate Change (IPCC). 2014. Climate Change 2014: Impacts, Adaptation, and Vulnerability. Contribution of Working Group II to the Fifth Assessment Report of the Intergovernmental Panel on Climate Change [Field, C.B., V.R. Barros, D.J. Dokken, K.J. Mach, M.D. Mastrandrea, T.E. Bilir, M. Chatterjee, K.L. Ebi, Y.O. Estrada, R.C. Genova, B. Girma, E.S. Kissel, A.N. 
(C) 2016, Elsevier. Licensed under the Creative Commons Attribution-NonCommercial-

NoDerivatives 4.0 International http://creativecommons.org/licenses/by-nc-nd/4.0/

Levy, S. MacCracken, P.R. Mastrandrea, L.L. White (eds.)]. Cambridge University Press, Cambridge, United Kingdom and New York, USA.

Jonsson M, Wardle D. 2009. The influence of freshwater-lake subsidies on invertebrates occupying terrestrial vegetation. Acta Oecol 35: 698-704.

Kaufman L, Rousseeuw PJ. 1990. Finding groups in data: an introduction to Cluster Analysis. Wiley, New York.

Kernan M, Ventura M, Bitušík P, Brancelj A, Clarke G, Velle G, Raddum GG, Stuchlík E, Catalan J. 2009. Regionalisation of remote European mountain lake ecosystems according to their biota: environmental versus geographical patterns. Freshwat Biol 54: 2470-93.

Khamis K, Hannah DM, Brown LE, Tiberti R, Milner a. M. 2014. The use of invertebrates as indicators of environmental change in alpine rivers and lakes. Sci Total Environ 493:1242-54.

Kopacek J, Stuchlik E, Straskrabova V, Psenakova P. 2000. Factors governing nutrient status of mountain lakes in the Tatra Mountains. Freshwat Biol 43 (3): 369-83.

Legendre P, Gallagher ED. 2001. Ecologically meaningful transformations for ordination of species data. Oecologia 129: 271-80.

López-Moreno JI, Goyettea S, Benistona M. 2008. Climate change prediction over complex areas: spatial variability of uncertainties and predictions over the Pyrenees from a set of regional climate models. Int J Climatol 28: 1535-1550.

Magnea U, Sciascia R, Paparella F, Tiberti R, Provenzale A. 2013. A model for high-altitude alpine lake ecosystems and the effect of introduced fish. Ecol Mod: 251: 211-20.

Manca M, Ruggiu D, Panzani P, Asioli A, Mura G, Nocentini AM. 1998. Report on a collection of aquatic organisms from high mountain lakes in the Khumbu Valley (Nepalese Himalayas). In: Lami A and Giussani G (eds), Limnology of high altitude lakes in the Mt Everest Region (Nepal). Mem Ist Ital Idrobiol 57: 77-98.

Oksanen J. 2008. Stepacross as flexible shortest paths or extended dissimilarities. R documentation for Vegan, available online at http://vegan.r-forge.r-project.org/.

Olofsson E, Melin E, Degerman E. 1995. The decline of fauna in small streams in the Swedish mountain range. Water Air Soil Pollut 85(2): 419-24.

Oswood MW, Miller LK, Irons III JG. 1991. Overwintering of freshwater benthic macroinvertebrates. In: Lee RE Jr, Denlinger DL (Eds), Insects at low temperature. Chapman and Hall, New York: 360-375.

R Development Core Team. 2005. R: a language and environment for statistical computing. R Foundation for Statistical Computing, Vienna, Austria. hhttp://www.R-project.orgi. 
(C) 2016, Elsevier. Licensed under the Creative Commons Attribution-NonCommercial-

NoDerivatives 4.0 International http://creativecommons.org/licenses/by-nc-nd/4.0/

Richter DD, Billings SA. 2015. One physical system: Tansley's ecosystem as Earth's critical zone. New Phytologist 206(3): 900-912.

Roberts DW. 1986. Ordination on the basis of fuzzy set theory. Vegetatio 66: 123-31.

Roberts DW. 2007a. FSO: fuzzy set ordination. R package version 1.0-1. hhttp://cran.R-project.orgi.

Roberts DW. 2007b. LabDSV: ordination and multivariate analysis for ecology. R package version 1.3-0 hhttp://cran.R-project.orgi.

Roberts DW. 2008. Statistical analysis of multidimensional fuzzy set ordinations. Ecology 89:1246-60.

Roberts DW. 2009. Comparison of multidimensional fuzzy set ordination with CCA and DB-RDA. Ecology 90(9): 2622-2634.

Schilling EG, Loftin CS, Huryn AD. 2009. Effects of introduced fish on macroinvertebrate communities in historically fishless headwater and kettle lakes. Biol Conserv 142: 3030-38.

Stone ML, Whiles MR, Webber JA, Williard KWJ, Reeve JD. 2005. Macroinvertebrate communities in agriculturally impacted southern Illinois streams: patterns with riparian vegetation, water quality, and in-stream habitat quality. J Environ Qual 34: 907-17.

Syväranta J, Jones RI. 2009. Isotopic variability in lake littoral organisms presents a challenge for food web studies. Verh Internat Verein Limnol 30(8): 1193-6.

Tachet H, Richoux P, Bournaud M, Usseglio-Polatera P. 2002. Invertébrés d'eau douce. Systématique, biologie, écologie. CNRS Editions, Paris, France [in French].

Thioulouse J, Chessel D, Doledee S, Olivier JM. 1997. ADE-4 A multivariate analysis and graphical display software. Stat Comput 7: 75-83.

Vadeboncoeur Y, McIntyre PB, Vander Zanden MJ. 2011. Borders of biodiversity: Life at the edge of the world's large lakes. BioScience 61 (7): 526-537.

Vander-Zanden MJ, Chandra S, Park S, Vade-Boncoeur Y, Goldman CR. 2006. Efficiencies of benthic and pelagic trophic pathways in a subalpine lake. Can J Fish Aquat Sci 63: 2608-20.

Vieites DR, Nieto-Román S, Palanca A. 1997. Alimentación de las ranas pardas, Rana gr. temporaria, en el Circo de Piedrafita (Pirineos, España). Pirineos 149: 91-104 [in Spanish].

Vollenweider RA. 1968. Scientific fundamentals of the eutrophication of lakes and flowing waters, with particular reference to nitrogen and phosphorus as factors in eutrophication. Organization for Economic Corporation and Development, Technical report, 250p. Paris, France.

Zaharescu, DG. 2011. Landscape ecology and geochemistry of high altitude lakes. PhD thesis, University of Vigo, Spain. 
(C) 2016, Elsevier. Licensed under the Creative Commons Attribution-NonCommercial-

NoDerivatives 4.0 International http://creativecommons.org/licenses/by-nc-nd/4.0/

Zaharescu DG, Hooda PS, Fernandez J, Soler AP, Burghelea Cl. 2009. On the arsenic-source mobilisation and its natural enrichment in the sediments of a high mountain cirque in the Pyrenees. Journal of Environmental Monitoring 11: 1973-1981.

Zaharescu DG, Hooda PS, Burghelea Cl, Palanca-Soler A. 2016a. A multiscale framework for deconstructing the ecosystem physical template of high altitudes lakes. Ecosystems (in press). bioRxiv doi: http://dx.doi.org/10.1101/034405.

Zaharescu DG, Palanca-Soler A., Hooda PS, Tanase C, Burghelea Cl, Lester RN. 2016b. Sensors of change: riparian ecosystem sensitivity to local and large scale gradients in high elevation lakes. bioRxiv doi: http://dx.doi.org/10.1101/035576. 
(C) 2016, Elsevier. Licensed under the Creative Commons Attribution-NonCommercialNoDerivatives 4.0 International http://creativecommons.org/licenses/by-nc-nd/4.0/

\section{Tables}

Table 1 Association between catchment variables characterising the Pyrenees lakes, and PCA components. Only highest variable correlation with any of the components is shown. This allowed to interpret PC1 as hydrodynamics, PC2 as geo-morphology and PC3 as topography formation.

\begin{tabular}{|c|c|c|c|}
\hline & \multicolumn{3}{|c|}{ Principal component } \\
\hline & 1 & 2 & 3 \\
\hline Tributary discharge & 0.92 & & \\
\hline Nature of tributary & 0.90 & & \\
\hline Nature of water output & 0.87 & & \\
\hline Lake size & 0.52 & & \\
\hline$\%$ grass covered slopes & & 0.72 & \\
\hline$\%$ grass covered shore & & 0.68 & \\
\hline Slope of lake perimeter & & -0.67 & \\
\hline Geology & & 0.60 & \\
\hline Aquatic vegetation & & 0.58 & \\
\hline Fractal order & & 0.50 & \\
\hline Catchment snow deposits & & & 0.86 \\
\hline Catchment type & & & 0.79 \\
\hline Shore snow coverage & & & 0.75 \\
\hline Connectivity with other lakes & & & 0.52 \\
\hline Total Eigenvalue (rotated) & 3.07 & 2.69 & 2.46 \\
\hline$\%$ of variance explained & 21.96 & 19.24 & 17.59 \\
\hline Cumulative \% & 21.96 & 41.20 & 58.79 \\
\hline
\end{tabular}

Rotation method: Varimax with Kaiser normalization.

Kaiser-Meyer-Olkin measure of sampling adequacy $=0.73$.

Bartlett's test of sphericity: approx. $\chi^{2}=1456.9(P<0.001)$. 
(C) 2016, Elsevier. Licensed under the Creative Commons Attribution-NonCommercialNoDerivatives 4.0 International http://creativecommons.org/licenses/by-nc-nd/4.0/

Table 2 Zoobenthic communities with significant association to lake groups (from prior cluster analysis), as given by indicator taxa analysis. A subject was classified into a group for which the indicator value was higher and significant (i.e. strong preference). Significance level is $<0.05$, unless stated otherwise.

\begin{tabular}{|c|c|c|c|}
\hline Taxon & Common name & Biota and lake groups & Indicator value \\
\hline Chironomidae Chironominae & Non-biting midges & $A$ & 0.67 \\
\hline Enchytraeidae & Microdrile oligochaetes & $A$ & 0.62 \\
\hline Chironomidae Tanypodinae & Non-biting midges & $A$ & 0.46 \\
\hline Chironomidae Orthocladiinae & Non-biting midges & $A$ & 0.46 \\
\hline Limnephilidae & Tube-case caddisflies & $A$ & 0.32 \\
\hline Sphaeriidae & Pea clams & $A$ & 0.23 \\
\hline Lumbriculidae & Microdrile oligochaetes & $A$ & 0.22 \\
\hline Naididae & Clitellate oligochaetes & $A$ & 0.22 \\
\hline Nematoda & Roundworms & $A$ & 0.21 \\
\hline Ceratopogonidae and Thaumaleidae & Biting \& solitary midges & $A$ & 0.15 \\
\hline Baetidae & Mayflies & $A$ & 0.11 \\
\hline Haliplidae & Crawling water beetles & $\mathrm{B}$ & 0.16 \\
\hline Aeshnidae & Dragonflies & B & $0.31(P=0.55)$ \\
\hline Limoniidae & Craneflies & $\mathrm{C}$ & 0.07 \\
\hline Culicidae & Mosquitoes & C & 0.03 \\
\hline Gordiacea & Horsehair worms & C & 0.03 \\
\hline Helophoridae & Water scavenger beetles & $\mathrm{C}$ & $0.12(P=0.16)$ \\
\hline
\end{tabular}


(C) 2016, Elsevier. Licensed under the Creative Commons Attribution-NonCommercialNoDerivatives 4.0 International http://creativecommons.org/licenses/by-nc-nd/4.0/

\section{Figure Captions}

Fig. 1 (a) Major biogeographical regions of Europe (after EEA, 2001). (b) Lakes distribution in the Pyrenees National Park, France (green boundaries). Only lakes within park boundaries, which are enclosed in the dash line box were considered for this study.

Fig. 2 One-dimensional fuzzy set ordination (FSO), showing the response of zoobenthic family structure to environmental variables in the Central Pyrenees lakes. Indices represent: (a) geolocation, (b) composite catchment (Table 1), (c) predation and (d) water physico-chemistry. Correlations are listed in descending order. Variables with highest influence in the model (correlations $>0.3$, in bold), also shown in plots, were retained for multidimensional FSO. $P$ represents the probability. Predation variables were Hellinger transformed (Legendre and Gallagher, 2001) previously to being used as predictors in the analysis.

Fig. 3 Multidimensional response of littoral invertebrate composition to geolocation and composite catchment factors in a multidimensional FSO (MFSO) with step-across improvement. Variables are added to the model as log transformed, in the order of their decreasing fuzzy correlation (Pearson) with biota dissimilarity matrix. Permutation number $=1000 . \gamma$ (gamma) represents a vector of the fraction of variance of a factor that is independent of all previous factors. Due to the high-dimensional variability of the dissimilarity matrix, the correlation probability for the one-dimensional solution sometimes has low significance, but it is still valid.

Fig. 4 Relationship between riparian vegetation structure and littoral invertebrate morphotype diversity and family richness in a bidimensional FSO. A step-across function improved the ordination. Number of permutations $=1000$.

Fig. 5 Major lake/ecosystem groups (A, B and C) as identified by hierarchical cluster analysis (flexible linkage, parameter $=0.85$ ) based on shared littoral invertebrate families. A plot of cluster solutions in discriminating space (inset) demonstrate an effective clustering. Illustrated are: (A) Cambales Valley lake, (B) Montferrat pond, Ossoue Valley and (C), Barroude Petit, Aure Valley. The results are from an analysis of 113 lakes and 46 major invertebrate groups. 
(C) 2016, Elsevier. Licensed under the Creative Commons Attribution-NonCommercialNoDerivatives 4.0 International http://creativecommons.org/licenses/by-nc-nd/4.0/

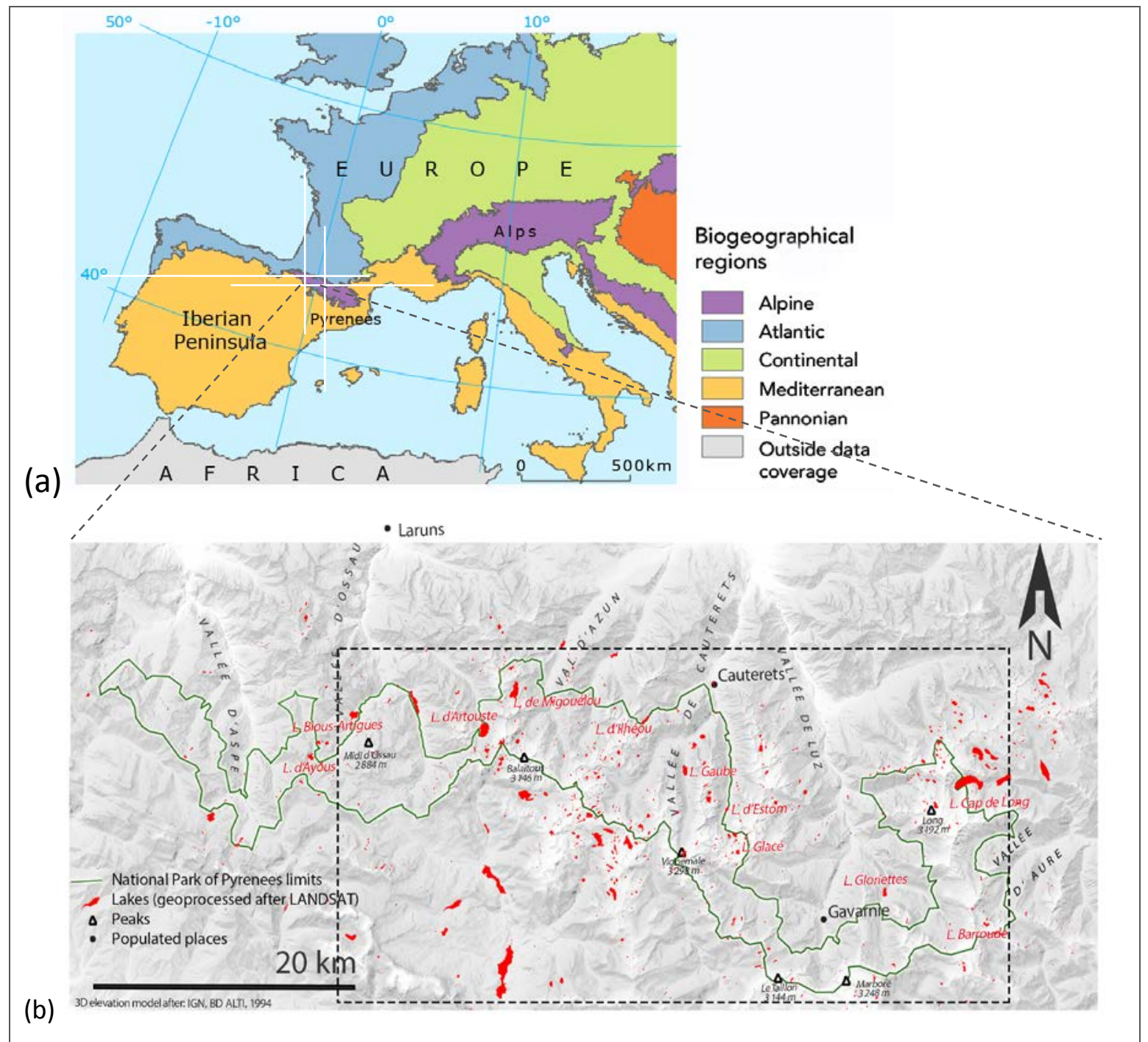

Figure 1 
(C) 2016, Elsevier. Licensed under the Creative Commons Attribution-NonCommercialNoDerivatives 4.0 International http://creativecommons.org/licenses/by-nc-nd/4.0/

\begin{tabular}{|c|c|c|c|}
\hline Factor & $r$ (Pearson) & $P$ & FSO plot ( $\mathrm{x}$-factor/y-apparent factor as predicted by biota) \\
\hline${ }^{\mathrm{a}}$ Longitude (UTM) & 0.547 & 0.001 & 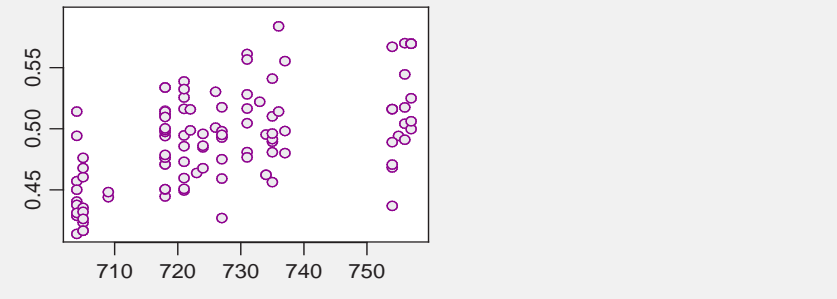 \\
\hline${ }^{a}$ Altitude (m a.s.l.) & 0.470 & 0.001 & 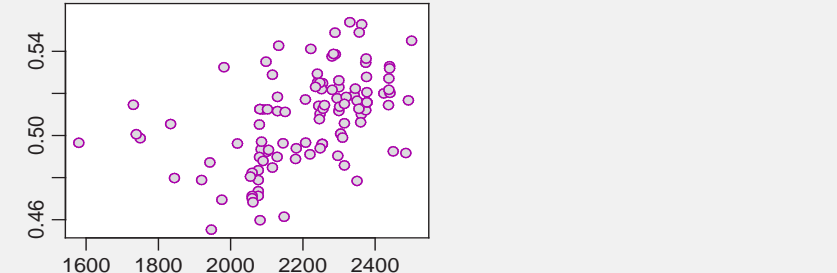 \\
\hline${ }^{\mathrm{a}}$ Latitude (UTM) & 0.336 & 0.001 & 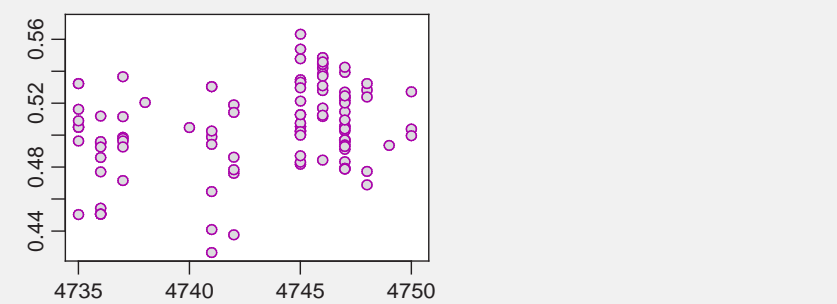 \\
\hline $\begin{array}{l}{ }^{\mathrm{b}} \text { Topography formation } \\
\text { (PCA regression factor scores) }\end{array}$ & 0.566 & 0.001 & 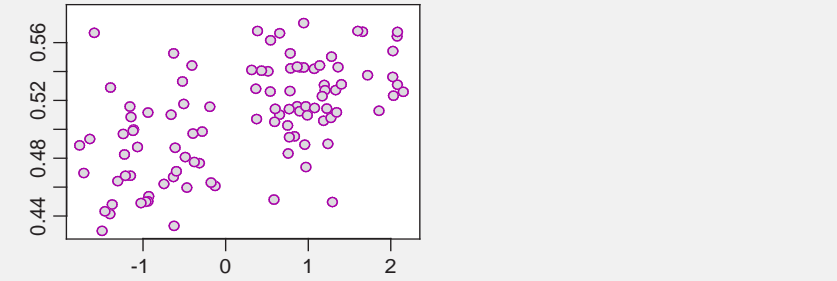 \\
\hline $\begin{array}{l}{ }^{\mathrm{b}} \text { Hydrodynamics } \\
\text { (PCA regression factor scores) }\end{array}$ & 0.439 & 0.001 & 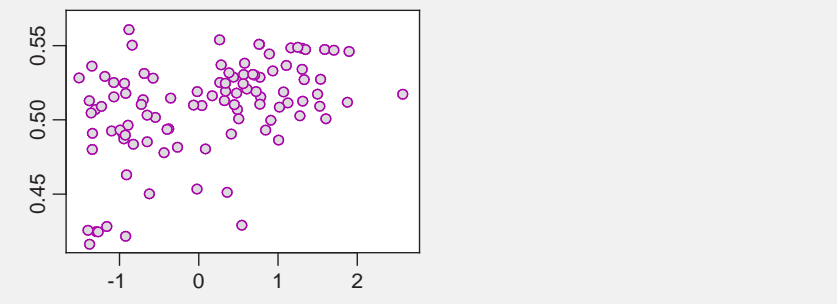 \\
\hline $\begin{array}{l}{ }^{\mathrm{b}} \text { Geo-morphology } \\
\text { (PCA regression factor scores) }\end{array}$ & -0.061 & 0.627 & \\
\hline${ }^{\mathrm{C}}$ Trout (presence/absence) & 0.068 & 0.277 & \\
\hline${ }^{\mathrm{c}}$ Frogs (presence/absence) & 0.052 & 0.296 & \\
\hline${ }^{\mathrm{d}} \mathrm{pH}$ (bottom) & 0.235 & 0.047 & \\
\hline${ }^{d} \mathrm{pH}($ surface $)$ & 0.074 & 0.278 & \\
\hline${ }^{d}$ Conductivity (surface) & 0.003 & 0.419 & \\
\hline${ }^{\mathrm{d}}$ Conductivity (bottom) & -0.009 & 0.457 & \\
\hline
\end{tabular}

Figure 2 
(C) 2016, Elsevier. Licensed under the Creative Commons Attribution-NonCommercialNoDerivatives 4.0 International http://creativecommons.org/licenses/by-nc-nd/4.0/

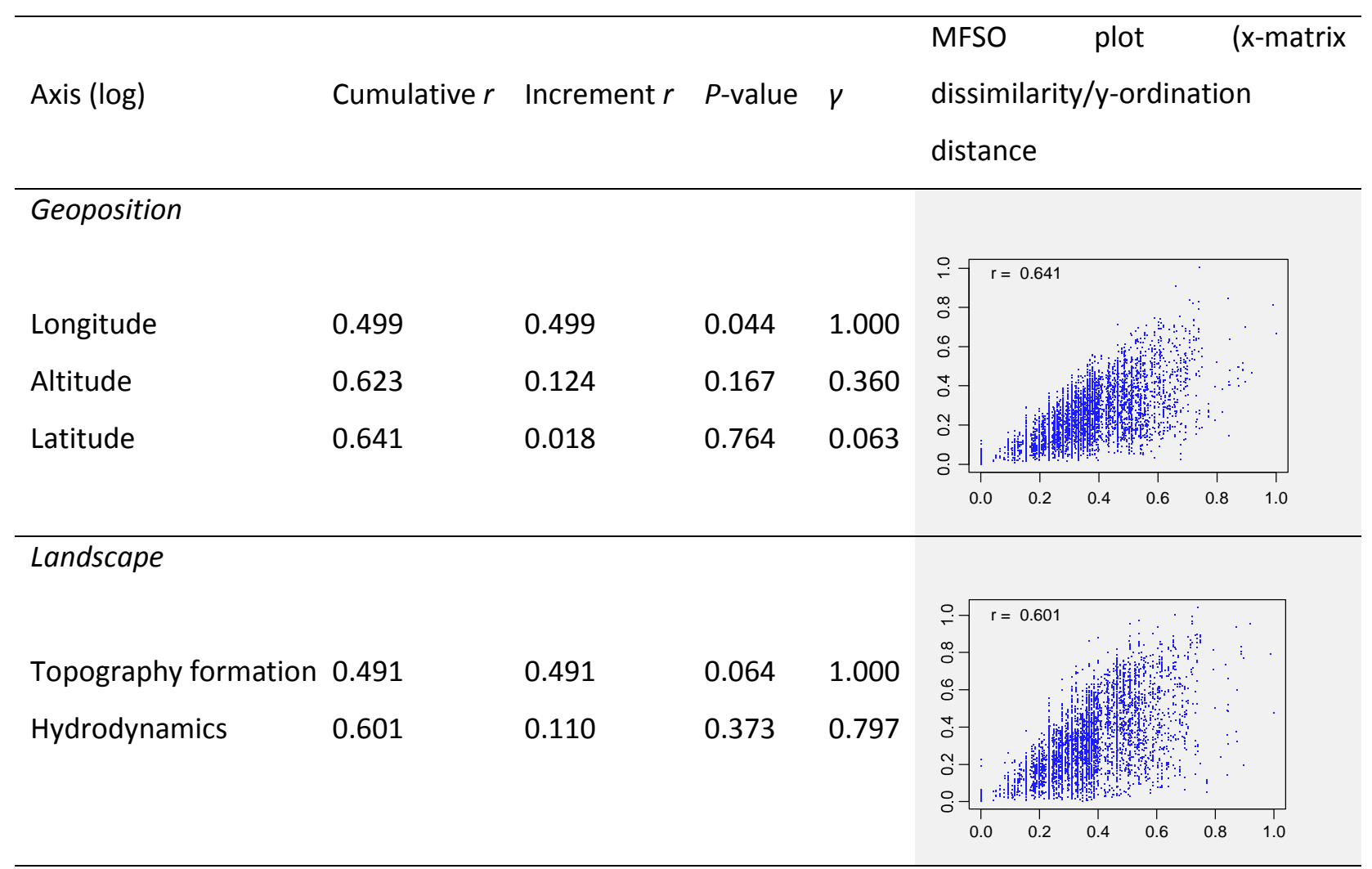

\section{Figure 3}


(C) 2016, Elsevier. Licensed under the Creative Commons Attribution-NonCommercialNoDerivatives 4.0 International http://creativecommons.org/licenses/by-nc-nd/4.0/

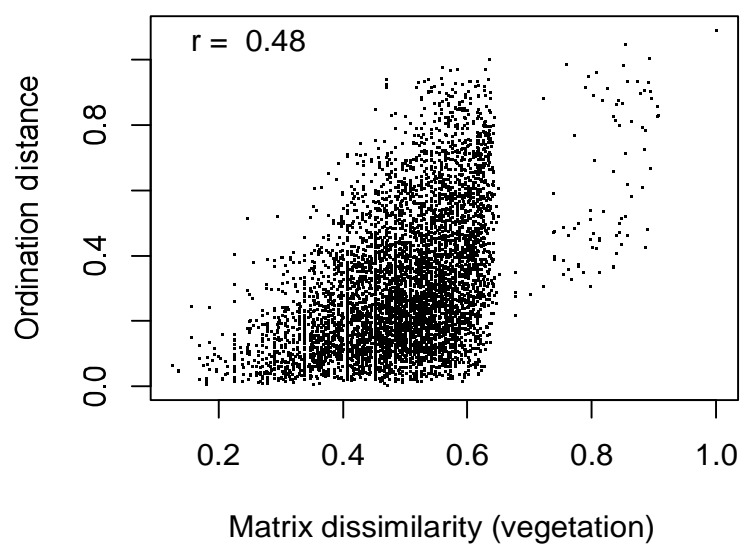

Figure 4 


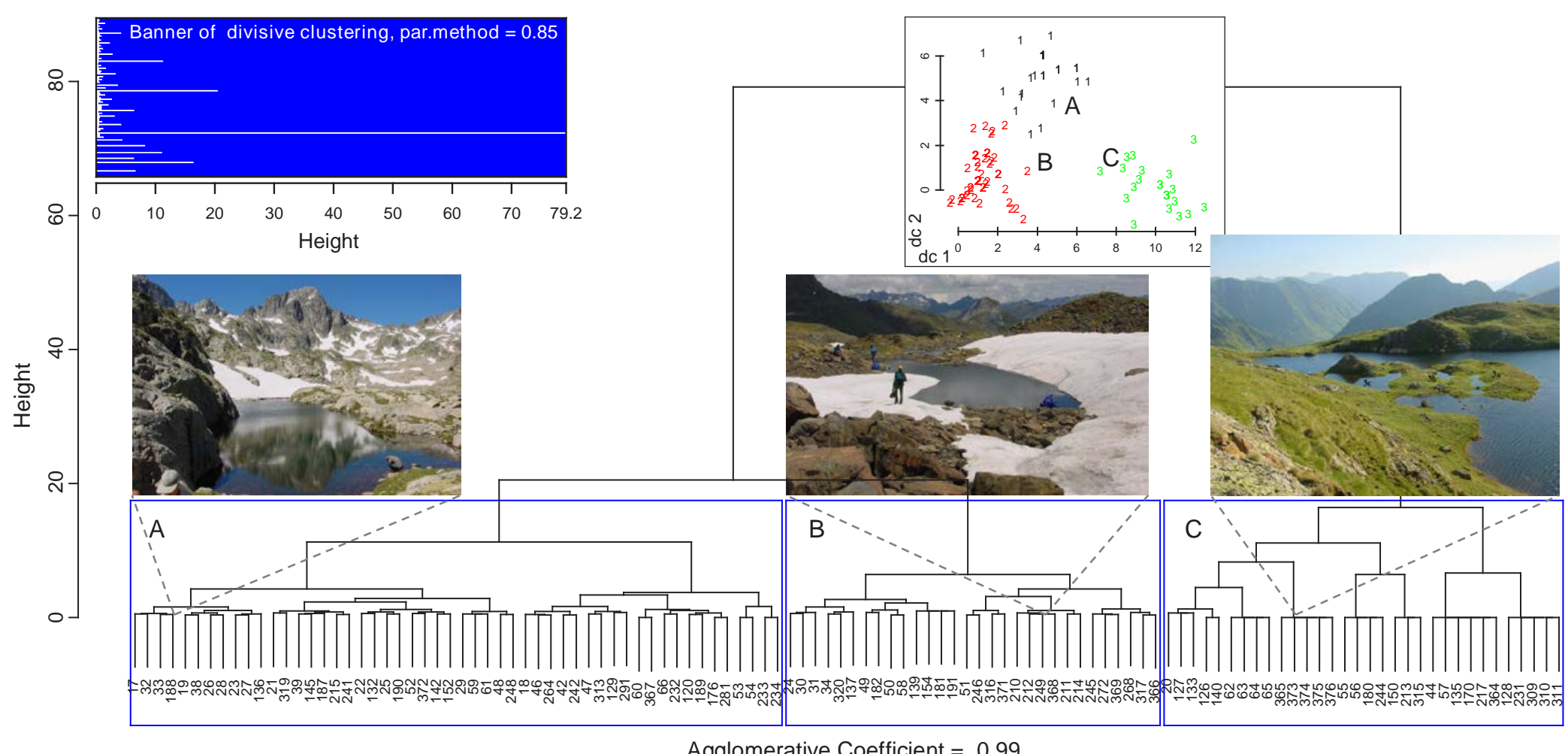

Figure 5 


\section{Supplementary Information}

\section{Small lakes in big landscape: Multi-scale drivers of littoral}

\section{ecosystem in alpine lakes}

Dragos G. Zaharescu, Carmen I. Burghelea, Peter S. Hooda, Richard N. Lester and Antonio Palanca-Soler

Supplementary List 1: Lakes and ponds from the central region of Pyrenees National Park surveyed in this study, together with their main hydrographical network, altitude (*below the tree line), geolocation (decimal degrees), surface area, $\mathrm{pH}$ and conductivity.

\begin{tabular}{|c|c|c|c|c|c|c|c|c|c|c|}
\hline \multicolumn{2}{|c|}{ Index Lake name } & \multirow{2}{*}{$\begin{array}{l}\text { Main } \\
\text { valley } \\
\text { Ossau }\end{array}$} & \multicolumn{3}{|c|}{$\begin{array}{l}\text { Altitude Latitude Longitude } \\
\text { m a.s.I. }\end{array}$} & \multirow{2}{*}{$\begin{array}{c}\begin{array}{c}\text { Area } \\
\mathrm{m}^{2}\end{array} \\
79223.11\end{array}$} & \multirow{2}{*}{$\begin{array}{c}\begin{array}{c}\mathrm{pH} \\
\text { (surface) }\end{array} \\
7.94\end{array}$} & \multirow{2}{*}{$\frac{\begin{array}{c}\mathrm{pH} \\
\text { (bottom) }\end{array}}{8.01}$} & \multicolumn{2}{|c|}{$\begin{array}{l}\text { Conductivity Conductivity } \\
\text { (surface), } \mu S \text { (bottom), } \mu S\end{array}$} \\
\hline 17 & Lake Berseau & & 2082 & 42.4959 & -0.3015 & & & & 23.00 & 24.00 \\
\hline 18 & Lake Berseau 1 & Ossau & 2080 & 42.4959 & -0.3015 & 1484.40 & 7.75 & 7.70 & 25.00 & 26.00 \\
\hline 19 & Lake Berseau 2 & Ossau & 2100 & 42.4959 & -0.3015 & 2419.81 & 7.63 & 7.63 & 14.00 & 14.00 \\
\hline 20 & Pond Berseau 1 & Ossau & 2085 & 42.4959 & -0.3015 & 127.23 & 7.47 & 7.47 & 9.00 & 9.00 \\
\hline 21 & Pond Berseau 2 & Ossau & 2086 & 42.4959 & -0.3015 & 180.64 & 7.69 & 7.69 & 25.00 & 25.00 \\
\hline 22 & Lake Larry 1 & Ossau & 2077 & 42.5018 & -0.3014 & 1162.39 & 8.09 & 7.78 & 31.00 & 32.00 \\
\hline 23 & Lake Larry 2 & Ossau & 2077 & 42.5018 & -0.3014 & 293.74 & 7.94 & 7.79 & 31.00 & 31.00 \\
\hline 24 & Lake Larry 3 & Ossau & 2077 & 42.5018 & -0.3014 & 414.69 & 7.30 & 7.30 & 30.00 & 30.00 \\
\hline 25 & Lake Larry 4 & Ossau & 2077 & 42.5018 & -0.3014 & 306.31 & 7.51 & 8.06 & 26.00 & 29.00 \\
\hline 26 & Lake Ayous 1 & Ossau & 2060 & 42.5018 & -0.2929 & 722.57 & 7.94 & 8.28 & 31.00 & 34.00 \\
\hline 27 & Lake Ayous 2 & Ossau & 2060 & 42.5018 & -0.2929 & 753.96 & 7.95 & 8.00 & 32.00 & 34.00 \\
\hline 28 & Lake Ayous 3 & Ossau & 2060 & 42.5018 & -0.2929 & 769.69 & 7.91 & 7.69 & 31.00 & 31.00 \\
\hline 29 & Lake Gentau 1 & Ossau & 1982 & 42.5018 & -0.2929 & 1850.40 & 8.57 & 8.68 & 62.00 & 62.00 \\
\hline 30 & Lake Gentau & Ossau & 1947 & 42.5018 & -0.2929 & 107068.62 & 8.03 & 8.33 & 40.00 & 45.00 \\
\hline 31 & Lake Miey & Ossau & 1920 & 42.5018 & -0.2929 & 9324.25 & 7.18 & 8.00 & 41.00 & 46.00 \\
\hline 32 & Lake Roumassot & Ossau & 1845 & 42.5018 & -0.2929 & 55694.15 & 8.52 & 8.55 & 43.00 & 45.00 \\
\hline 33 & Lake Castérau & Ossau & 1943 & 42.4945 & -0.2931 & 15013.67 & 8.60 & 8.68 & 121.00 & 127.00 \\
\hline 34 & Lake Paradis & Ossau & 1976 & 42.4945 & -0.2931 & 9495.97 & 8.20 & 8.11 & 53.00 & 54.00 \\
\hline 38 & Lake Col de Peyreget 1 & Ossau & 2220 & 42.4941 & -0.2635 & 1473.41 & 7.85 & 8.14 & 11.00 & 19.00 \\
\hline 39 & Lake Col de Peyreget 2 & Ossau & 2208 & 42.4941 & -0.2635 & 3758.13 & 7.74 & 7.71 & 6.00 & 6.00 \\
\hline 42 & Lake Arrémoulit Supérieur & Ossau & 2281 & 42.5005 & -0.1957 & 39654.75 & 6.46 & 6.71 & 20.00 & 22.00 \\
\hline 44 & Lake Arrémoulit (below dam) & Ossau & 2255 & 42.5037 & -0.1956 & 9680.03 & 7.79 & 7.98 & 13.00 & 15.00 \\
\hline 46 & Lake Palas 1 & Ossau & 2365 & 42.5037 & -0.1956 & 2511.70 & 7.94 & NA & 8.00 & NA \\
\hline 47 & Lake Palas 2 & Ossau & 2362 & 42.5037 & -0.1956 & 1226.79 & 8.06 & 7.60 & 5.00 & 9.00 \\
\hline 48 & Lake Arrémoulit Superior 1 & Ossau & 2300 & 42.5037 & -0.1956 & 1272.35 & 7.90 & 7.98 & 5.00 & 7.00 \\
\hline 49 & Lake Arrémoulit Superior 2 & Ossau & 2295 & 42.5037 & -0.1956 & 208.92 & 5.46 & 5.46 & 9.00 & 9.00 \\
\hline 50 & Lake Arrémoulit Superior 3 & Ossau & 2297 & 42.5037 & -0.1956 & 23.56 & 5.28 & 5.19 & 7.00 & 9.00 \\
\hline 51 & Lake Arrémoulit Superior 4 & Ossau & 2300 & 42.5037 & -0.1956 & 2104.08 & 7.34 & 6.92 & 3.00 & 5.00 \\
\hline 52 & Lake Arrémoulit Superior 5 & Ossau & 2300 & 42.5037 & -0.1956 & 1503.25 & 5.51 & 5.60 & 3.00 & 5.00 \\
\hline 53 & Lake Arrémoulit Superior 6 & Ossau & 2305 & 42.5037 & -0.1956 & 1237.00 & 8.04 & 7.38 & 5.00 & 6.00 \\
\hline 54 & Lake Arrémoulit Superior 6A & Ossau & 2305 & 42.5037 & -0.1956 & 1236.97 & 8.02 & 7.83 & 5.00 & 6.00 \\
\hline 55 & Lake Arrémoulit Superior 7 & Ossau & 2290 & 42.5037 & -0.1956 & 384.85 & 7.37 & 6.90 & 2.00 & 4.00 \\
\hline 56 & Lake Arrémoulit Superior 8 & Ossau & 2285 & 42.5037 & -0.1956 & 144.51 & 6.41 & 5.98 & 4.00 & 5.00 \\
\hline 57 & Lake Arrémoulit Inférieur & Ossau & 2241 & 42.5037 & -0.1956 & 9671.11 & 7.45 & 7.38 & 14.00 & 18.00 \\
\hline 58 & Lake Arrémoulit Inferior 1 & Ossau & 2248 & 42.5037 & -0.1956 & 292.17 & 5.81 & 5.81 & 3.00 & 3.00 \\
\hline 59 & Lake Arrémoulit Inferior 2 & Ossau & 2246 & 42.5037 & -0.1956 & 2831.36 & 6.47 & NA & 14.00 & $\mathrm{~N}$ \\
\hline 60 & Lake Arrémoulit Inferior 3 & Ossau & 2244 & 42.5037 & -0.1956 & 4970.00 & 7.15 & NA & 14.00 & $\mathrm{~N}$ \\
\hline 61 & Lake Arrémoulit Inferior 4 & Ossau & 2256 & 42.5037 & -0.1956 & 523.85 & 6.90 & 6.90 & 4.00 & 4.00 \\
\hline 62 & Lake Arrémoulit Inferior 5A & Ossau & 2254 & 42.5037 & -0.1956 & 282.74 & 6.38 & 6.38 & 5.00 & 5.0 \\
\hline
\end{tabular}




\begin{tabular}{|c|c|c|c|c|c|c|c|c|c|c|}
\hline 63 & Lake Arrémoulit Inferior 5B & Ossau & 2254 & 42.5037 & -0.1956 & 271.74 & 6.18 & 6.18 & 7.00 & 7.00 \\
\hline 64 & Lake Arrémoulit Inferior 5C & Ossau & 2254 & 42.5037 & -0.1956 & 278.02 & 6.77 & 6.77 & 8.00 & 8.00 \\
\hline 65 & Lake Arrémoulit Inferior 5D & Ossau & 2254 & 42.5037 & -0.1956 & 266.24 & 6.40 & 6.40 & 4.00 & 4.00 \\
\hline 66 & Lake Arrémoulit Inferior 6 & Ossau & 2252 & 42.5037 & -0.1956 & 197.92 & 6.32 & 6.32 & 5.00 & 5.00 \\
\hline 120 & Lake Micoulaou 1 & Azun & 2302 & 42.5034 & -0.1744 & 706.84 & 7.84 & 7.84 & 13.00 & 13.00 \\
\hline 127 & Lake Batcrabère Supérieur 1 & Azun & 2182 & 42.5034 & -0.1744 & 285.88 & 7.75 & 7.92 & 14.00 & 15.00 \\
\hline 128 & Lake Batcrabére Milieu & Azun & 2130 & 42.5034 & -0.1744 & 1923.44 & 7.89 & 8.48 & 16.00 & 19.00 \\
\hline 129 & Pond Batcrabére Milieu 1 & Azun & 2130 & 42.5106 & -0.1743 & 47.12 & 7.91 & 7.91 & 23.00 & 23.00 \\
\hline 132 & Lake below Batcrabére Milieu & Azun & 2129 & 42.5034 & -0.1744 & 1755.31 & 7.82 & 7.82 & 16.00 & 16.00 \\
\hline 133 & Lake Batcrabère Inférieur & Azun & 2116 & 42.5106 & -0.1743 & 18605.53 & 7.93 & 8.17 & 20 & 21 \\
\hline 135 & Lake Batcrabère Inférieur 1 & Azun & 2116 & 42.5106 & -0.1743 & 3573.56 & 7.47 & 7.72 & 19.00 & 25.00 \\
\hline 136 & Pond next to Larribet Refuge & Azun & 2055 & 42.5106 & -0.1743 & 1979.20 & 5.98 & 5.98 & 10.00 & 10.00 \\
\hline 137 & Pond Pabat & Azun & 2062 & 42.5106 & -0.1743 & 518.35 & 6.01 & 7.32 & 4 & 6 \\
\hline 139 & Lake La Claou Supérieur & Azun & $1750^{*}$ & 42.521 & -0.1656 & 2964.09 & 8.32 & 8.24 & 19.00 & 22.00 \\
\hline 140 & Lake La Claou & Azun & $1739 *$ & 42.521 & -0.1656 & 2035.75 & 8.2 & 8.2 & 20 & 20 \\
\hline 142 & Lake Doumblas & Azun & $1580 *$ & 42.5209 & -0.1612 & 1796.99 & 8.28 & 8.28 & 30.00 & 30.00 \\
\hline 145 & Pond Pluviometre & Azun & 1731 & 42.5135 & -0.1529 & 4546.54 & 8.22 & 8.22 & 23.00 & 23.00 \\
\hline 150 & Lake Remoulis Supérieur & Azun & 2019 & 42.5031 & -0.1532 & 12801.99 & 8.28 & 8.48 & 28.00 & 30.00 \\
\hline 152 & Pond Casteric & Azun & 2080 & 42.4958 & -0.1533 & 659.73 & 7.98 & 8.36 & 23.00 & 28.00 \\
\hline 154 & Pond Toue & Azun & 2090 & 42.4958 & -0.1533 & 639.31 & 7.24 & 7.60 & 33.00 & 27.00 \\
\hline 170 & Lake Cambalés 2 & Cauterets & 2424 & 42.4924 & -0.1407 & 7297.92 & 7.87 & 8.72 & 7.00 & 13.00 \\
\hline 176 & Lake Cambalés Grand & Cauterets & 2342 & 42.4924 & -0.1407 & 13994.22 & 8.31 & 8.43 & 13.00 & 19.00 \\
\hline 180 & Pond Opale & Cauterets & 2222 & 42.4923 & -0.1323 & 175.93 & 8.04 & 8.04 & 21.00 & 21.00 \\
\hline 181 & Pond Opale 1 & Cauterets & 2248 & 42.4923 & -0.1323 & 54.98 & 8.29 & 8.29 & 6.00 & 6.00 \\
\hline 182 & Pond Opale 2 & Cauterets & 2260 & 42.4923 & -0.1323 & 1412.15 & 7.70 & NA & 32.00 & NA \\
\hline 187 & Pond Petit Laquet & Cauterets & 2360 & 42.4923 & -0.1323 & 169.65 & 7.83 & 7.83 & 8.00 & 8.00 \\
\hline 188 & Lake Petit Laquet & Cauterets & 2350 & 42.4923 & -0.1323 & 3765.98 & 7.94 & 8.16 & 5.00 & 9.00 \\
\hline 189 & Lake Costalade Supérieur & Cauterets & 2320 & 42.4923 & -0.1323 & 9519.03 & 7.93 & 8.31 & 12.00 & 5.00 \\
\hline 190 & Pond Cambalés & Cauterets & 2315 & 42.4923 & -0.1323 & 829.38 & 8.05 & 8.38 & 14.00 & 15.00 \\
\hline 191 & Lake Costalade Inférieur & Cauterets & 2310 & 42.4923 & -0.1323 & 10148.92 & 8.16 & 8.23 & 13.00 & 16.00 \\
\hline 210 & Lake Col d'Arratille & Cauterets & 2501 & 42.4709 & -0.1033 & 2670.28 & NA & NA & NA & NA \\
\hline 211 & Pond Arratille 1 & Cauterets & 2363 & 42.4741 & -0.1031 & 141.37 & 7.64 & 7.72 & 59.00 & 43.00 \\
\hline 212 & Pond Arratille 2 & Cauterets & 2330 & 42.4741 & -0.1031 & 63.62 & 7.50 & 7.50 & 45.00 & 45.00 \\
\hline 213 & Pond Arratille 3 & Cauterets & 2315 & 42.4741 & -0.1031 & 3691.37 & 8.75 & NA & 85.00 & NA \\
\hline 214 & Pond Arratille 4 & Cauterets & 2289 & 42.4741 & -0.1031 & 31.42 & 7.93 & 7.93 & 15.00 & 15.00 \\
\hline 215 & Pond Arratille 5 & Cauterets & 2315 & 42.4741 & -0.1031 & 731.21 & 8.44 & 8.61 & 91.00 & 87.00 \\
\hline 217 & Lake Arratille & Cauterets & 2247 & 42.4741 & -0.1031 & 70038.67 & 8.32 & 8.31 & 77.00 & 74.00 \\
\hline 231 & Oulettes. glacier runoff & Cauterets & 2151 & 42.4707 & -0.0905 & 2434.66 & 7.00 & 7.00 & 90.00 & 90.00 \\
\hline 232 & Pond Arraillé Inférieur & Cauterets & 2441 & 42.4706 & -0.0821 & 714.71 & 7.72 & 7.01 & 34.00 & 29.00 \\
\hline 233 & Lake Arraillé Milieu & Cauterets & 2450 & 42.4706 & -0.0821 & 2544.69 & 6.92 & 7.08 & 25.00 & 26.00 \\
\hline 234 & Lake Arraillé Supérieur & Cauterets & 2485 & 42.4706 & -0.0821 & 2206.12 & NA & NA & NA & NA \\
\hline 241 & Pond Montferrat & Luz & 2207 & 42.4455 & -0.0743 & 109.96 & 7.40 & 6.83 & 19.00 & 9.00 \\
\hline 242 & Lake Montferrat & Luz & 2374 & 42.4455 & -0.0743 & 10445.80 & 6.81 & 7.28 & 56.00 & 42.00 \\
\hline 244 & Pond Montferrat 2 & Luz & 2440 & 42.4455 & -0.0743 & 1011.59 & 7.78 & 7.47 & 38.00 & 37.00 \\
\hline 245 & Lake Montferrat 1 & Luz & 2438 & 42.4455 & -0.0743 & 2111.15 & 7.42 & 7.58 & 84.00 & 73.00 \\
\hline 246 & Lake Montferrat 3 & Luz & 2438 & 42.4455 & -0.0743 & 302.38 & 7.53 & 7.53 & 73.00 & 73.00 \\
\hline 248 & Lake Montferrat 5 & Luz & 2437 & 42.4455 & -0.0743 & 314.15 & NA & NA & NA & NA \\
\hline 249 & Lake Montferrat 6 & Luz & 2440 & 42.4455 & -0.0743 & 500.30 & 8.43 & 8.43 & 5.00 & 5.00 \\
\hline 264 & Pond Sentier d'Estom 1 & Cauterets & 2235 & 42.4703 & -0.0653 & 320.44 & 7.25 & 7.60 & 69.00 & 54.00 \\
\hline 268 & Pond Sentier d'Estom 3 & Cauterets & 2240 & 42.4703 & -0.0653 & 243.47 & 7.70 & 7.63 & 19.00 & 19.00 \\
\hline 272 & Lake Labas & Cauterets & 2281 & 42.4702 & -0.0609 & 49542.92 & 7.84 & 7.78 & 50.00 & 48.00 \\
\hline 281 & Pond Turon Couy 2 & Cauterets & 2492 & 42.463 & -0.0611 & 471.24 & 7.56 & 7.88 & 10.00 & 10.00 \\
\hline 291 & Lake Ossue & Luz & 1834 & 42.4525 & -0.0614 & 38954.6 & 7.58 & 7.80 & 117.00 & 108.00 \\
\hline 309 & Lake Aires Supérieur & Luz & 2089 & 42.4329 & 0.0607 & 8251.15 & 7.27 & NA & 199.00 & NA \\
\hline 310 & Lake Aires Inférieur 1 & Luz & 2081 & 42.4329 & 0.0607 & 1865.32 & 7.90 & 7.89 & 146.00 & 165.00 \\
\hline 311 & Lake Aires Inférieur 2 & Luz & 2081 & 42.4329 & 0.0607 & 7314.41 & 7.91 & 7.92 & 174.00 & 178.00 \\
\hline 313 & Lake Comble 1 & Luz & 2098 & 42.4327 & 0.0651 & 6660.18 & 7.66 & 7.60 & 175.00 & 166.00 \\
\hline 315 & Pond Troumouse 1 & Luz & 2105 & 42.4329 & 0.0607 & 11.78 & 8.15 & 8.15 & 60.00 & 60.00 \\
\hline 316 & Pond Troumouse 2 & Luz & 2102 & 42.4329 & 0.0607 & 9.42 & 7.78 & 7.78 & 61.00 & 61.00 \\
\hline 317 & Pond Troumouse 3 & Luz & 2133 & 42.4329 & 0.0607 & 25.13 & 7.60 & 7.60 & 38.00 & 38.00 \\
\hline 319 & Lake Troumouse3 & Luz & 2145 & 42.4329 & 0.0607 & 5006.91 & 6.97 & 6.97 & 88.00 & 88.00 \\
\hline 320 & Lake Troumouse 4 & Luz & 2148 & 42.4329 & 0.0607 & 1209.51 & 7.95 & 7.95 & 156.00 & 156.00 \\
\hline 364 & Pond Barroude 6 & Aure & 2345 & 42.4326 & 0.0735 & 400.55 & 8.62 & 8.30 & 12.00 & 11.00 \\
\hline
\end{tabular}




\begin{tabular}{|c|c|c|c|c|c|c|c|c|c|c|}
\hline 365 & Pond Barroude 5 & Aure & 2350 & 42.4326 & 0.0735 & 1157.68 & 8.10 & 8.16 & 43.00 & 42.00 \\
\hline 366 & Pond Barroude 4 & Aure & 2356 & 42.4326 & 0.0735 & 1762.43 & 7.28 & 7.14 & 52.00 & 54.00 \\
\hline 367 & Pond Barroude 3 & Aure & 2374 & 42.4326 & 0.0735 & 668.37 & 7.91 & 8.01 & 90.00 & 92.00 \\
\hline 368 & Pond Barroude 2 & Aure & 2375 & 42.4326 & 0.0735 & 186.92 & 7.53 & 7.96 & 20.00 & 23.00 \\
\hline 369 & Pond Barroude 1 & Aure & 2376 & 42.4325 & 0.0819 & 803.46 & 6.71 & 7.52 & 118.00 & 116.00 \\
\hline 371 & Pond Barraode refuge & Aure & 2377 & 42.4325 & 0.0819 & 9.42 & NA & NA & NA & NA \\
\hline 372 & Lake Barroude Grand & Aure & 2355 & 42.4325 & 0.0819 & 53603.42 & 7.80 & 8.38 & 151.00 & 267.00 \\
\hline 373 & Lake Barroude Petit & Aure & 2377 & 42.4325 & 0.0819 & 62682.63 & 6.88 & 8.19 & 49.00 & 57.00 \\
\hline 374 & Pond Barroude Petit 1 & Aure & 2377 & 42.4325 & 0.0819 & 11.78 & 8.26 & 8.30 & 90.00 & 80.00 \\
\hline 375 & Pond Barroude Petit 2 & Aure & 2377 & 42.4325 & 0.0819 & 12.57 & 8.52 & 8.48 & 54.00 & 49.00 \\
\hline 376 & Pond Barroude Petit 3 & Aure & 2377 & 42.4325 & 0.0819 & 62.83 & NA & NA & NA & NA \\
\hline \multicolumn{2}{|c|}{ Mean } & & 2212 & $42.481-C$ & 130892 & 7219.74 & 7.58 & 7.66 & 38.25 & 38.32 \\
\hline \multicolumn{2}{|c|}{ Maximum } & & 2501 & 42.52 & 0.08 & 107068.62 & 8.75 & 8.72 & 199.00 & 267.00 \\
\hline \multicolumn{2}{|c|}{ Minimum } & & 1580 & 42.43 & -0.30 & 9.42 & 5.28 & 5.19 & 2.00 & 3.00 \\
\hline
\end{tabular}

Supplementary List 2: Major zoobenthos taxa and their incidence in the 114 lakes, ponds and pools of this study.

\begin{tabular}{ll}
\hline Taxon & N. lakes \\
\hline O. Diptera, sO. Nematocera, SF. Psychodoidea, F. Psychodidae & 1 \\
O. Diptera, sO. Nematocera, SF. Culicoidea, F. Dixidae & 1 \\
O. Diptera, sO. Nematocera, SF. Culicoidea, F. Culicidae & 1 \\
O. Diptera, sO. Nematocera, SF. Chironomoidea, F. Ceratopogonidae \& F. Thaumaleidae & 7 \\
O. Diptera, sO. Nematocera, SF. Chironomoidea, F. Chironomidae, sF. Tanypodinae & 25 \\
O. Diptera, sO. Nematocera, SF. Chironomoidea, F. Chironomidae, sF. Chironominae & 40 \\
O. Diptera, sO. Nematocera, SF. Chironomoidea, F. Chironomidae, sF. Orthocladiinae (lato sensu)= (stricto & 59 \\
sensu) sF. Orthocladiinae+ sF. Diamesinae+ sF. Prodiamesinae & \\
O. Diptera, sO. Nematocera, SF. Tipuloidea, F. Tipulidae & 1 \\
O. Diptera, sO. Nematocera, SF. Tipuloidea, F. Limoniidae & 2 \\
O. Diptera, sO. Brachycera, SF. Empidoidea & 1 \\
O. Trichoptera, GR. Spicipalpia, SF. Rhyacophiloidea, F. Rhyacophilidae & 1 \\
O. Trichoptera, GR. Spicipalpia, SF. Hydroptiloidea, F. Hydroptilidae & 1 \\
O. Trichoptera, GR. Integripalpia, SF. Limnephiloidea, F. Limnephilidae & 52 \\
O. Trichoptera, GR. Integripalpia, SF. Limnephiloidea, F. Uenoidae & 4 \\
O. Coleoptera, sO. Adephaga, F. Haliplidae & 2 \\
O. Coleoptera, sO. Adephaga, F. Dytiscidae & 28 \\
O. Coleoptera, sO. Polyphaga, GR. Haplogastra (=GR. Palpicornia), SF. Hydrophiloidea, F. Hydrophilidae & 2 \\
O. Coleoptera, sO. Polyphaga, GR. Haplogastra (=GR. Palpicornia), SF. Hydrophiloidea, F. Helophoridae & 13 \\
O. Coleoptera, sO. Polyphaga, GR. Heterogastra, SF. Byrrhoidea, F. Elmidae (=F. Helminthidae, =F. & 7 \\
Elminthidae) & \\
O. Megaloptera, F. Sialidae & 8
\end{tabular}


O. Heteroptera, iO. Nepomorpha, F. Corixidae 15

O. Heteroptera, iO. Gerromorpha, F. Mesoveliidae 2

O. Heteroptera, iO. Gerromorpha, F. Veliidae 1

O. Heteroptera, iO. Gerromorpha, F. Gerridae $\quad 6$

O. Odonata, sO. Anisoptera, F. Aeshnidae 1

O. Odonata, sO. Anisoptera, F. Gomphidae $\quad 1$

O. Plecoptera, SF. Nemouroidea, F. Nemouridae 1

O. Plecoptera, SF. Nemouroidea, F. Capniidae $\quad 2$

O. Plecoptera, SF. Perloidea, F. Chloroperlidae \& F. Perlodidae 3

O. Ephemeroptera, F. Baetidae $\quad 8$

O. Ephemeroptera, F. Siphlonuridae 1

O. Ephemeroptera, F.Heptageniidae 1

Cl. Lamellibranchia, SF. Corbiculacea, F. Sphaeriidae 22

Cl. Gasteropoda, sCl. Prosobranchiata, F. Valvatidae $\quad 1$

Cl. Gasteropoda, sCl. Prosobranchiata, F. Hydrobiidae $\quad 1$

Cl. Gasteropoda, sCl. Pulmonata, F. Ancylidae $\quad 2$

Cl. Gasteropoda, sCl. Pulmonata, F. Lymnaeidae 11

Phyl. Annelida, Cl. Hirudinea, O. Rhynchobdelliformes, F. Glossiphoniidae 1

Phyl. Annelida, Cl. Oligochaeta, F. Naididae $\quad 19$

Phyl. Annelida, Cl. Oligochaeta, F. Tubificidae $\quad 2$

Phyl. Annelida, Cl. Oligochaeta, F. Lumbriculidae $\quad 15$

Phyl. Annelida, Cl. Oligochaeta, F. Enchytraeidae 39

Phyl. Annelida, Cl. Oligochaeta, F. Lumbricidae \& F. Sparganophilidae $\quad 1$

Phyl. Nemathelminthes, Cl. Nematoda $\quad 24$

Phyl. Nemathelminthes, Cl. Gordiacea $\quad 1$

Phyl. Plathelmintes, Cl. Turbelariata, O. Triclades, F. Planariidae 2

Abbreviations: Phyl.= Phylum; Cl.= Class; O.= Order; GR.= Group and F.= Family.

Prefixes: $\mathrm{S}=$ super-; s=sub- and $\mathrm{i}=$ infra-. 

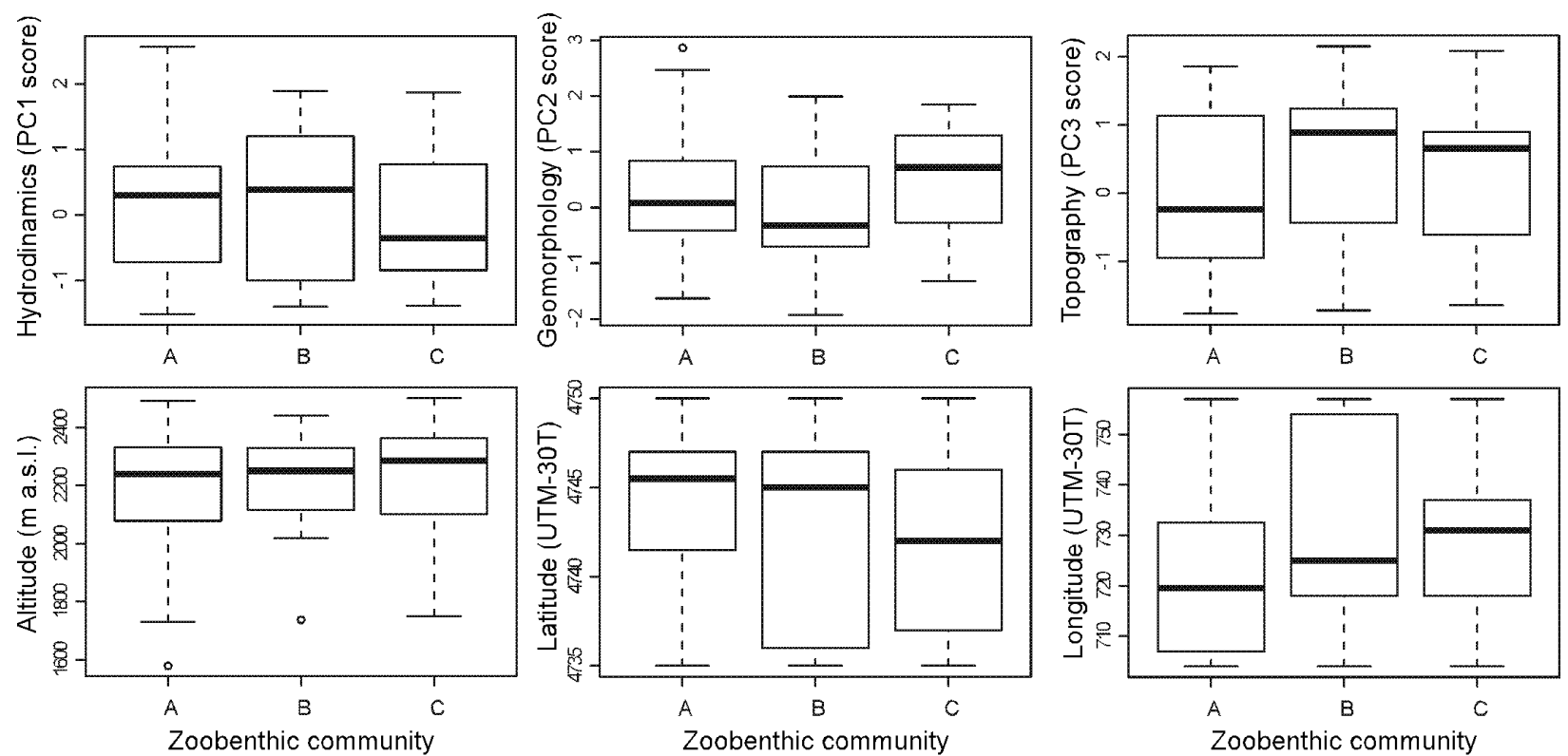

Supplementary Figure 1 Distribution of major zoobenthic communities (Table 2) along catchment scale (hydrodynamics, geo-morphology and topography formation, as summarized by principal component analysis) and geographical scale (altitude, latitude and longitude) gradients in the Central Pyrenees. 